\title{
Green Power? European Normative Influence on Chinese Environmental Policy
}

\author{
Zsuzsa Anna Ferenczy, Ph.D. \\ European Parliament \\ zsuzsaanna.ferenczy@europarl.europa.eu
}

\begin{abstract}
This article claims that-notwithstanding limitations-in environmental cooperation with China Europe has been effective in projecting international norms that China has shown interest in embracing. On the one hand, European normative power effectiveness is due to its power of example in global environmental issues and Beijing's acknowledgement of Europe's leading global role in this area. On the other hand, it is a result of Beijing's recognition of the urgency of the issue domestically, indispensable to secure further economic growth and global influence. This suggests the relevance of the power of domestic interest to Beijing's approach towards international cooperation with international standards as pursued by Europe. Persisting limitations to Europe's effectiveness, however, include the normative divergence burdening relations with China, and its fragmented governance system. In addition, the economic, political and social problems Europe is facing following the 2008 financial crisis have challenged its global standing, constraining its normative ambitions concerning China.
\end{abstract}

Keywords: European normative power; China; environmental cooperation; normative divergence; 2008 financial crisis; constructivism

\section{Introduction}

For decades, the EU's integration process has nurtured debate about its growing relevance as an important global actor in the international community. The notion of normative power has been at the core of academic research on developments in Europe's international "actorness", alongside competing concepts such as civilian power and military power. ${ }^{1}$ Ian Manners noted that the power of ideas has been influential in the evolution of the European Community into the European Union. The concept implies that the EU promotes a series of normative principles that, within the United Nations system, are acknowledged as universally applicable. These principles are enshrined in EU law, lie at the heart of European policies and are promoted via its

\footnotetext{
${ }^{1}$ See for example H. Bull, Civilian Power Europe: A Contradiction in Terms? Journal of Common Market Studies, Vol. 21, No. 2, 1982, pp.149-64.; F. Duchêne, 'The European Community and the Uncertainties of interdependence', in M. Kohnstamm and W. Hager (eds.) A Nation Writ Large? Foreign-Policy Problems before the European Community, London, Macmillan, 1973; K. Smith, Beyond the Civilian Power EU Debate, Politique européenne, No. 17, 2005, pp. 63-82; T. Diez, Constructing the Self and Changing Others: Reconsidering 'Normative Power Europe', University of Birmingham, 2005; R. Whitman, Road Map for a Route March? Decivilianizing through the EU's Security Strategy, European Foreign Affairs Review 11, 2006, pp. 1-15; W. Trott, An Analysis of civilian, military and normative power in EU foreign policy, University of Leeds, POLIS Journal vol. 4, 2010.
} 
external action: "sustainable peace, freedom, democracy, human rights, rule of law, equality, social solidarity, sustainable development and good governance". ${ }^{2}$ Normative power ambitions are now found in Europe's relations with the rest of the world. It is in this spirit that Europe has developed its China policy, including in the area of environmental cooperation. John Vogler and Hannes Stephan ${ }^{3}$ noted that as a normative power, European environmental diplomacy and its effort to make the WTO "greener" can be conceived of as projections of its identity as a green power

Since the establishment of diplomatic relations in 1985, EU-China relations have evolved into a strategic partnership. This entails an institutional cooperation in over sixty sectoral dialogues in economic and political affairs, as well as people-to-people contact. It is based on the articulation of commitments to jointly pursue issues of common interest and tackle global challenges together. The four decades of strengthening bilateral cooperation have however led to a level of complexity that increasingly hinder, instead of supporting, the strategic nature of the relations, and mutual trust is lacking. Since its reform and opening up in 1978, China has grown into a global actor with global power ambitions, seeking to translate its economic weight into political influence as an active participant of the international community. This increase in China's international presence has significantly changed the dynamics of EU-China relations.

It has fueled the perception that China joining the group of leading economies and casting its economic and political shadow and system of governance globally would threaten Western international influence and the existing world order. These developments have raised awareness - and alarm-in the EU that while the EU remains committed to shaping China, China is also shaping Europe's development, with increased intensity following the 2008 global financial crisis. Therefore, the EU's influence on China can no longer be adequately assessed without addressing China's influence on the EU. In the past decade the EU's international standing and influence have decreased, just as China's has increased. This article claims two factors in particular have played a central role in this process, namely Europe's inner fragmentation and the normative divergence in EU-China relations. Beyond these factors, most importantly it is Europe's power of example that has been key to the EU's normative power effectiveness. Efforts to better understand the impact of the shift in EU-China relations on European normative power are therefore timely.

Realism and liberalism have been the leading and competing International Relations theoretical approaches to the study of European power, challenged by constructivism. While no single theory explains it, they all contribute to understanding the EU's behaviour as an international actor. Constructivism focuses on norms and ideas as the social context in which actors relate to each other, socialise and shape identity, and looks at how this context impacts states' behavior. A theoretical approach introduced by Nicholas Onuf in 1989, constructivism is based on the notion that international relations are socially constructed. 4 The approach was further refined by Alexander

\footnotetext{
${ }^{2}$ I. Manners, Normative Power Europe: The International Role of the EU, Panel discussion: The European Union between International and World Society, European Community Studies Association, Madison, Wisconsin, USA, 2001.

3 J. Vogler and H. R. Stephan, The European Union in Global Environmental Governance: Leadership in the Making? International Environmental Agreements, 7 (2007): 389-413.

4 N. Onuf, Worlds of Our Making: The Strange Career of Constructivism in International Relations, Columbia, SC, University of South Carolina Press, 1989.
} 
Wendt in the 1990s. 5 The materialist-rationalist approach sees these same actors determined to act in accordance with the benefits they have to gain, much less impacted by ideas, beliefs and identity. Within the constructivist and realist frameworks, and against perceptions of decreasing European relevance, this article argues that in environmental cooperation European normative power has been effective. This has been largely due to Europe's power of example, which academics widely perceive as solid. A growing body of literature suggests that, since the 1990s, a number of multilateral environmental agreements bear Europe's fingerprints, promising to extend its environmental standards beyond its immediate jurisdiction. ${ }^{6}$ European international leadership is documented around climate change, hazardous chemicals and waste, mercury abatement, air and marine pollution and biodiversity protection.

As an international actor with globally recognised leadership in environmental protection, the EU has assisted China's integration into the international community. In 2015, in the EU-China joint summit statement celebrating forty years of relations, the two sides agreed to address key challenges such as air, water and soil pollution. 7 Based on the assessment of European policy papers, this article considers the following issues as top priorities the EU has actively pursued in cooperation with China: 1 . water; 2. air pollution; 3 . waste management; 4 . biodiversity and 5 . climate change. These correspond with China's environmental priorities in its own development agenda. In Mao Zedong's time, the leadership saw the environment in China as an object to be exploited for economic growth and political campaigns. ${ }^{8}$ In a radical shift, current Chinese President Xi Jinping said the environment should be protected "like we protect our eyes" and treated "like it is our lives". 9 The Chinese leadership recognised that in order to further advance its economic achievements, China needs European expertise. Determined to strengthen its global relevance, Beijing perceived cooperation in its best interest and both partners identified the issue an area of common interest.

Both the power of norms and international standards as pursued by the EU, and the power of China's domestic interests shaped the EU's normative power effectiveness. Official Chinese rhetoric and policy-making have gradually adjusted the country's development with the environment as a top priority. This implies a slow embracing of international norms. As such, in 2014 Premier Li Keqiang declared "war on pollution", identifying drinking water source protection, key watershed pollution control and recovery, soil pollution and recovery as some of the main priorities of the Clean Water Action Plan. ${ }^{10}$ The feedback effect of this led to "the gradual reconception of its domestic interests to align more closely with the norms of international institutions"; "compliance was deepest when international pressures and domestic interests converged". ${ }^{11}$ This paper first introduces European normative power in EU-China

\footnotetext{
5 A. Wendt, Social Theory of International Politics, Cambridge Studies in International Relations, Cambridge University Press, 1999, p. 1.

${ }^{6} \mathrm{~K}$. Schulze and J. Tosun, External dimensions of European environmental policy: An analysis of environmental treaty ratification by third states, European Journal of Political Research, 52 (2013): 581-607.

7 European External Action Service, EU-China Summit joint statement, The way forward after forty years of EUChina cooperation, 2015.

${ }^{8}$ A. H. F. Li, Hopes of Limiting Global Warming? China and the Paris Agreement on Climate Change, China Perspectives, 2016.

9 Comments by President Xi on eco-environmental protection, China Environment Media, 2016,

http://www.chinaenvironment.info/Important_Message/201602/t20160222_24137.html, accessed 13 May 2018. ${ }^{10}$ D. Tan, The War of Water Pollution, ChinaWater Risk, 2014.

${ }^{11}$ A. Kent, Compliance v Cooperation: China and International Law, Australian International Law Journal, vol. 13, 2008, pp. 19-32.
} 
relations, considering the two main factors shaping it, i.e. fragmentation and normative divergence, in light of the 2008 global financial crisis. Second, it looks at European environmental priorities regarding China, which are water, air, waste, biodiversity and climate change, assessing European normative power effectiveness.

\section{European normative power and EU-China relations after the 2008 global financial crisis}

Reflections on "actorness", in particular on Europe as a non-state actor, have unfolded with the debate on European integration. In classical realism, the term "international actor" is synonymous with "nation state". With the continued development of the European project into a regional organisation, the centrality of the state and the place of military power in realist thinking have been challenged. The history of modern "actorness" theory is therefore a history of the attempt to understand the European Community/Union's place in the international system. ${ }^{12}$ As the debate on definitions of "actorness" advanced, in the 1990s, David Allen and Michael Smith 13 argued Western Europe is neither a purely dependent entity, nor a fully-fledged state-like actor, contending that only a state-like structure could be considered a true actor. They developed the notion of "presence", as a counterpoint to the focus on "actorness", manifesting itself in four forms: initiator, shaper, barrier and filter. ${ }^{14}$ )

Following Gunnar Sjöstedt's attempt in the 1970s to measure the European Community's actorness, in 1993 Christopher Hill conceptualised Europe as a non-state actor, suggesting that the application of the state-centered realist view to Europe has damaged its "image as a powerful and progressive force in the reshaping of the international system”. ${ }^{15}$ Contrasting Hill's statement with Hedley Bull's renowned words of 1982 "Europe is not an actor in international affairs, and does not seem likely to become one" 16 demonstrates the great strides made that lead to Ian Manners' perception of the EU's international role as primarily a normative power. The concept of European normative power focuses primarily on Europe's "co-integration", a unique process that allows developing characteristics of governance and international identity, which transcend the limitations of states and international society. ${ }^{17}$ As such, the EU is founded on shared sovereignty, which has led to the coexistence of supranational and intergovernmental levels in EU decision-making. As a normative power, in its relations with third countries, the EU promotes the very principles that are enshrined in EU law and lie at the heart of its own foundation, including democracy, human rights and rule of law.

\footnotetext{
${ }^{12}$ For more see M. Doidge, 'Regional organization as actors in international relations. Interregionalism and assymetric dialogues', in J. Rüland, G. Schubert, C. Schucher and Cornelia Storz (eds.) Asian-European Relations, Building blocks for global governance? Routledge Contemporary Asia Series, $1^{\text {st }}$ edition, 2008.

13 D. Allen and M. Smith, 'Western Europe's Presence in the Contemporary International Arena' in M. Holland, (ed.), The Future of European Political Cooperation: Essays on Theory and Practice, 1991, New York: St. Martin Press.

14 R. Whitman, The Fall, and Rise, of Civilian Power Europe? National Europe Center paper, 2002, no. 16.

${ }_{15} \mathrm{M}$. Doidge, 'Regional organization as actors in international relations. Interregionalism and assymetric dialogues', in J. Rüland, G. Schubert, C. Schucher and Cornelia Storz (eds.) Asian-European Relations, Building blocks for global governance? Routledge Contemporary Asia Series, $1^{\text {st }}$ edition, 2008.

${ }^{16}$ H. Bull, Civilian Power Europe: A Contradiction in Terms? Journal of Common Market Studies, Vol. 21, No. 2 (1982): 149-64.

17 I. Manners, Normative Power Europe: The International Role of the EU, Panel discussion: The European Union between International and World Society, European Community Studies Association, Madison, Wisconsin, USA, 2001.
} 
Most importantly, the extent to which the EU sets an example at home in respecting the norms it wants to project shapes its credibility and capacity to project them externally. Europe's inner fragmentation, its multi-layered structure between member states and institutions has led to a complex policy-making process, including in the area of environmental policy, implying a dynamic combination of policies on institutional and member-state level. European environmental policy is a shared competency between member states and institutions, whereby national perspectives can clash at the expense of coordination, thus weakening the EU's ability to act in an exemplary manner and engage China as one. Therefore, this fragmentation affecting environmental policy-making is closely linked to Europe's power of example. In general Europe's leading role as a green power has been acknowledged. Scholars have looked at the relationship between the institutional set-up of European foreign policymaking and the EU's international "actorness", for example in the establishment of the UN Framework Convention on Climate Change. They found the EU showed a relatively high degree of international "actorness". ${ }^{18}$ This was seen as the combined result of the considerable congruence of member states' initial preferences and the social interaction among them, and between them and non-EU actors, through which preferences converged even further. Nevertheless, perceptions of Europe's record have been diverse. Many policy efforts have produced mixed results, shaped by a host of regional, national and local political economic factors, and substantial implementation and policy integration challenges remain across member states. ${ }^{19}$ When Europe does not act as a role model, its power of example suffers and the effectiveness of its normative power weakens.

Furthermore, a normative divergence burdens the EU-China strategic partnership, affecting all bilateral cooperation. Politically speaking, there is a "fundamental value gap" between the two: between Europe's traditional Western liberalism, enshrined by democracy, human rights and economic freedoms, and the authoritarian perspective of the Chinese communist party, also officially referred to as "socialism with Chinese characteristics". ${ }^{20}$ The two sides display fundamental differences between their systems of governance and state-society-individual relations. Europe views human rights, democracy and rule of law as mutually reinforcing international principles, and, as a normative power, pursues them together. China has not rejected these values, it has actually enshrined them into its Constitution. ${ }^{21}$ Yet, other values occupy a more prominent role in the official agenda. These are inspired by the Five Principles of Peaceful Coexistence, including equality, mutual benefit, the sanctity of sovereignty

\footnotetext{
${ }_{18}$ M Groenleer and L. G. Van Schaik, United we stand? The European Union's International Actorness in the Cases of the International Criminal Court and the Kyoto Protocol, Journal of Common Market Studies, vol. 45, nr. 5 (2007): 969-998.

19 Selin and VanDeveer, Broader, Deeper, Greener, 2015.

20 J.C. Gottwald, A. Cottey and N. Underhill, 'The European Union and China: Status, Issues, Prospects' in N. Sausmikat, K. Fristsche, (eds.) Civil Society in European-Chinese Relations, Challenges of Cooperation, EUChina Civil Society Forum, 2010, https://www.tni.org/files/download/eu-china-civil-society.pdf, accessed 7 May 2018.

${ }^{21}$ For example, article 33 of the Constitution of the People's Republic of China stipulates "All persons holding the nationality of the People's Republic of China are citizens of the People's Republic of China. All citizens of the People's Republic of China are equal before the law. The State respects and preserves human rights". Article 35: "Citizens of the People's Republic of China enjoy freedom of speech, of the press, of assembly, of association, of procession and of demonstration”. For more see Constitution of the People's Republic of China, Full text after amendment on March 14, 2004, available at http://www.npc.gov.cn/englishnpc/Constitution/200711/15/content_1372964.htm, accessed 16 May 2018.
} 
and non-interference. ${ }^{22}$ As both partners have seen their global relevance grow, albeit to a different extent, they both face domestic and international demands for more responsibility in addressing global problems, including climate change.

The protection of the environment has undoubtedly become an issue where the question of global responsibility and the concept of sovereignty have become most relevant, issues evoking normative differences in EU-China relations. In 2011 the EU recognised that international environmental governance is weak due to the fact that the new roles and responsibilities of emerging economies are not sufficiently defined. The European Commission considered this to be due to institutional fragmentation, a lack of accountability for implementing policies, a lack of human and financial resources, and the lack of a strong and authoritative voice within the global governance system. ${ }^{23}$ China has equally called for greater representation of developing countries in the global governance system. ${ }^{24}$ While the two sides agree on the need to strengthen environmental governance, differences remain in the way they approach reform. The notion of sovereignty has been a dividing issue in EU-China relations. For the Chinese leadership, the sanctity of sovereignty makes any outside criticism on politically sensitive issues, such as calls for a greater role for civil society in environmental protection, seem as interference in China's domestic affairs. In contrast, on the European front, it is sovereignty sharing that defines EU-level decision-making. Notwithstanding this practice, in the past decade, in particular since the series of crises within the EU, the concept has been challenged in the EU. Member states remain divided on how to tackle the many challenges the EU is facing, including migration, even leading to calls to take national sovereignty back from Brussels. National capitals fear the EU institutions are overstepping their authority. This is reflected in the strengthening of Eurosceptic politics across Europe, also seen via Brexit.

In fact, following successful economic and political integration that turned the European Community of six into the European Union of twenty-eight, the EU is now dealing with an identity crisis. ${ }^{25}$ Faced with a financial crisis, an unprecedented migration crisis at its eastern and southern shores, international terrorism, security challenges and domestic problems including the rise of the far right and Brexit, Europe's ability to address challenges as a mature global power, and to respond to these internally as a responsible power is being questioned. In the aftermath of 2008 "a new EU reality has emerged", and has accelerated a number of trends already visible in recent years: two-speed Europe becoming a reality, the ideal of an egalitarian Europe giving way to the reality of political dominance by larger countries, and the alliance between France and Germany, long the motor of European integration, weakening. ${ }^{26}$ As a result, Europe's leverage over China has unavoidably been impacted. Beyond the EU, the entire West and western liberalism - with the US at the centerhas come under attack. The 2008 financial crisis was a turning point in the role of emerging powers in global reordering; the crisis not only led them to play a major role

\footnotetext{
${ }^{22}$ Ministry of Foreign Affairs of the PRC, China's Initiation of the Five Principles of Peaceful Co-existence, http://www.fmprc.gov.cn/mfa_eng/ziliao_665539/3602_665543/3604_665547/t18053.shtml, accessed 13 May 2018.

${ }^{23}$ European Commission, Rio+2O: towards the green economy and better governance, Brussels, COM (2011)363final, 2011, http://eur-lex.europa.eu/legalcontent/EN/TXT/PDF/?uri=CELEX:52011DCo363\&from=EN, accessed 7 May 2018.

24 Xi speaks for developing countries in UN, offers new outlook on development, int'l relations, Xinhuanet, 2015 , http://www.xinhuanet.com/english/china/2015-09/29/c_134671859.htm, accessed 7 May 2018.

${ }_{25}$ European Commission, José Manual Durao Barroso State of the Union 2012 Address, 2012,

http://europa.eu/rapid/press-release_SPEECH-12-596_en.htm?locale=en _accessed 10 May 2018.

${ }^{26}$ K. Barysch, A New Reality for the European Union, Council on Foreign Relations, September, 2010.
} 
in fashioning the global response to the crisis, but also created opportunities to shape the debate over future global governance and world order. ${ }^{27}$

China's relations with the EU have undergone major changes since 2008, impacting the effectiveness of the EU's normative power. Beijing has shown readiness to bail out Europe, considering it to be a common interest to have "a united European Union, a prosperous Europe and a strong euro", as Premier Li Keqiang remarked during his 2015 visit to Brussels. ${ }^{28}$ In the process, China's success in riding out the crisis has inspired greater outward self-confidence, sometimes even hubris (de Jonquières, 2015). In contrast, Europe's struggle has made it more anxious and divided. Chinese observers argue Chinese investment, via the granting of market economy status and a bilateral investment treaty, could ease tensions between the core and the periphery in Europe which could contribute politically to European integration, a central goal of long-term Chinese foreign policy. ${ }^{29}$

Views on how to handle China's role in addressing Europe's economic challenges continue to diverge. While some have embraced Chinese infrastructure initiatives in Europe as an economic opportunity, in general Brussels fears they will further divide Europe and common European interest, as EU institutional discourse on China increasingly suggests. For example, the 2018 European Parliament resolution on the state of EU-China relations calls on member states participating in the $16+1$ format "to ensure that their participation in this format enable the EU to have one voice in its relationship with China". ${ }^{30}$ This approach is fully in line with the 2016 EU-China joint communication, which stated that the EU "must project a strong, clear and unified voice in its approach to China", just as it insisted that cooperation under the format should have an overall outcome that "is beneficial for the EU as a whole". ${ }^{31}$ And, in response to China's growing influence, the European Commission called China a "systemic rival promoting alternative models of governance" in its March 2019 strategic outlook on EU-China relations, signaling a significant shift in EU discourse. ${ }^{2}$

This shift appears more compatible with the China-approach the current American President Donald Trump has advocated in the past two years, which in itself is also reflective of a shift towards more robustness in US-China relations, "an increasingly zero-sum, unilateralist, protectionist, and nativist 'America First' approach". 33 Both the EU and the United States have taken a tough stance against China-and in general all foreign investment in sensitive industries-and have initiated stricter rules on investment in areas such as defence, high-tech and infrastructure as a matter of

\footnotetext{
27 A. Acharya, The End of American World Order, Polity Press, 2014.

${ }^{28}$ Li says Beijing will keep buying European bonds, China Daily, 2015,

http://usa.chinadaily.com.cn/epaper/2015-06/30/content_21143082.htm,accessed 10 May 2018.

${ }_{29}$ Z. Shi, China-EU Relations: Crisis and Opportunity, The Diplomat, 2016,

http://thediplomat.com/2016/o3/china-eu-relations-crisis-and-opportunity/2 accessed 12 May 2018.

$3^{\circ}$ European Parliament, Resolution of 12 September 2018 on the state of EU-China relations (2017/2274(INI)) http://www.europarl.europa.eu/sides/getDoc.do?pubRef=-//EP//TEXT+TA+P8-TA-2018-

$0343+\mathrm{O}+\mathrm{DOC}+\mathrm{XML}+\mathrm{Vo} / / \mathrm{EN} \&$ language=EN, accessed on 5 April 2019.

${ }^{31}$ European Commission, Joint Communication to the European Parliament and the Council, Elements for a new EU strategy on China, JOIN(2016) 30 final,

http://eeas.europa.eu/archives/docs/china/docs/joint_communication_to_the_european_parliament_and_the _council_-_elements_for_a_new_eu_strategy_on_china.pdf, accessed 5 April 2019.

$3^{2}$ European Commission, Joint Communication to the European Parliament, the European Council and the

Council, EU-China - A strategic outlook, https://ec.europa.eu/commission/sites/beta-

political/files/communication-eu-china-a-strategic-outlook.pdf, accessed 6 April 2019.

33 D. Dollar, R. Hyas, and J.A. Bader, Assessing US-China relations 2 years into the Trump presidency, Brookings,

January 15, 2019, https://www.brookings.edu/blog/order-from-chaos/2019/01/15/assessing-u-s-china-relations2-years-into-the-trump-presidency/, accessed 6 April 2019.
} 
national security. In the midst of a trade war with China, the US federal government passed legislation introducing a rigorous review system and restrictions aimed at curbing Chinese investment in 27 sensitive sectors, including telecommunications, aircraft manufacturing, aluminum production and others. 34 The EU established a framework for the screening of foreign direct investment into the EU, following several cases of high-profile acquisitions of critical infrastructure and sensitive technology by Chinese state-owned companies. 35 And, in the spirit of reciprocity, Western countries continue demanding more market access and transparency from China.

Nevertheless, it is key to note that tension has also risen within the transatlantic relationship, with a United States showing signs of questioning the international order it originally helped set up. The differences have become visible in the approach to multilateralism on the two sides of the Atlantic, whereby the EU remains committed to upholding, while the US seems ready to question and undermine it. This development, starting with the election of President Trump, has had a significant impact on the international order, also shaping EU-China relations. In fact, in climate change and environmental protection, the two sides seemed to join forces in the absence of a US leadership in global efforts. This challenge to the system has thus created an interesting opportunity both for the EU and China to take on a more prominent global role, and possibly do so together. In an unexpected turn, it is Chinese President Xi Jinping who called for respect of multilateralism in global affairs at the 2018 G20 summit in Argentina for example, just as the American President has pursued protectionism through domestic policies, such as “America First”. ${ }^{36}$

Concerning China, in the past four decades, it has acquired remarkable economic weight and stepped up efforts to gradually translate this into political clout and diplomatic influence. The launch of the 16+1 Platform for infrastructure investment involving eleven Central Eastern European member states and five Western Balkans countries, the Asian Infrastructure Investment Bank (AIIB) and the Belt and Road Initiative (BRI) all seem to suggest Beijing's global ambition to take China's "going out" policy, as announced in 2001, to the next level. Similarly, the President's 2012 China Dream - to double the 2010 GDP by 2020 and build a modern socialist countryreflects the leadership's aspiration to become the world's leading nation. 37 A confident official narrative has taken shape in China, and language has become more upfront on the global role the leadership has in mind for the country. The introduction of the "Xi Jinping Thought on Socialism with Chinese Characteristics for a New Era" into the constitution in 2017 is another move in this direction. ${ }^{38}$ This suggests moving away

\footnotetext{
34 In New Slap at China, U.S. Expands Power to Block Foreign Investment. The New York Times, Oct. 10, 2018, https://www.nytimes.com/2018/10/10/business/us-china-investment-cfius.html, accessed 7th April 2019. 35 There have been several high-profile acquisitions of European companies by Chinese companies. For example, in 2016 Chinese home appliance company Midea took over the German industrial robotics suppliers Kuka for the value of 4.5 billion euro. It was a controversial takeover which raised alarms about the sale of a national champion to China, both in Berlin and in EU institutions in Brussels. Since then Germany, like other EU member states, tightened rules for non-EU share purchases or acquisitions of entities that are in its critical infrastructure. On EUlevel, in March 2019 the Council approved a new framework to screen foreign direct investments coming into the EU, meant to safeguard Europe's security, public order and strategic interests. For more see The Council, Regulation of the European Parliament and of the Council establishing a framework for the screening of foreign direct investment into the Union, https://data.consilium.europa.eu/doc/document/PE-72-2018-INIT/en/pdf, accessed 7 April 2019.

${ }^{36}$ China's call for multilateralism at G20 summit echoed by experts worldwide. Xinhua, 2018, http://www.xinhuanet.com/english/2018-12/02/c_137644628.htm, accessed 7 April 2019.

${ }_{37}$ Chinese dream is a dream for all. Xinhua, 2016, http://www.xinhuanet.com/english/201612/03/c_135878166.htm, accessed 10 May 2018.

${ }^{8}$ Backgrounder: Xi Jinping Thought on Socialism with Chinese Characteristics for a New Era. Xinhua, 2018, http://www.xinhuanet.com/english/2018-03/17/c_137046261.htm accessed 24 May 2018.
} 
from the identity of a developing country seeking global status to an already mature global actor ready to take on further responsibilities as a global power, deserving a stronger voice. The narrative of China as a global power has strengthened perceptions-and concerns-in the West that through its mammoth projects Beijing is in fact working on providing an alternative to the developing world which undermines fundamental principles of democracy, the rule of law and human rights. And considering the challenges to Western liberal democracy, taking advantage of the global leadership vacuum, Beijing can pursue its global ambitions with more confidence.

For example, in October 2017 at the 19th Congress of the Communist Party of China the President called on all countries to build an open, inclusive, clean and beautiful world, and to take a new approach to developing state-to-state relations with communication, not confrontation. ${ }^{39}$ Similarly, at the April 2018 Boao Forum the Chinese President urged dialogue and not confrontation following an escalating trade dispute between China and the United States, calling for global leadership on climate and more international cooperation on several fronts, in particular trade.40 Questions whether through its grand ambitions Beijing will try to maintain, reform or replace the existing open, integrated and rule-based liberal Western-centered system, are valid. However, as Ikenberry has argued, it may be possible for China to overtake the US alone, but it is much less likely China will ever manage to overtake the Western order. ${ }^{41}$ Western relative decline therefore remains a matter of inconclusive debate. Nevertheless, considering the scale of global problems, China's assent and the level of its global influence appear essential to effectively address international problems in an increasing number of fields, including climate change.

Academics have acknowledged that China made impressive headway in moving away from its reliance on coal and oil and that Europe has facilitated the country's shift to clean energy sources; between 2004 and 2006 not less than twenty-two workshops and conferences were organised within the framework of the Energy Environment Program, set up between China and the European Commission to stimulate the development of clean coal technologies, energy efficiency and renewable energies. $4^{2}$ Chinese leaders have acknowledged the imminent danger resulting from the rapid economic growth and promised to address it. European officials believe "there is a genuine wish among policymakers in China to learn from EU experience". 43 Environment Commissioner Karmenu Vella stressed, "Some of China's most recent environmental regulations are based on EU precursors". 44 In this spirit, the EU-China

\footnotetext{
${ }_{39} \mathrm{Xi}$ Jinping speech delivered at the 19th National Congress of the Communist Party of China, Xinhuanet, 2017, http://www.xinhuanet.com/english/download/Xi_Jinping's_report_at_19th_CPC_National_Congress.pdf 2 accessed 12 May 2018.

$4^{\circ}$ China's Xi Jinping urges dialogue, not confrontation, at Boao Forum after Trump seeks tariffs, The Straits Times, 2018, http://www.straitstimes.com/asia/east-asia/chinas-xi-says-opening-brings-progress-closure-leadsto-backwardness-at-boao-forum, accessed 12 May 2018.

${ }^{41}$ G. J. Ikenberry, The Rise of China and the Future of the West, Foreign Affairs, January/February, 2008.

${ }^{42} \mathrm{~J}$. Holslag, China's energy policy in the light of climate change, and option for cooperation with the EU, Policy Department Economic and Scientific Policy, European Parliament, 2007,

http://www.europarl.europa.eu/RegData/etudes/etudes/join/2007/393501/IPOL-

JOIN_ET(2007)393501_EN.pdf, accessed 10 May 2018.

43 European Commission, China Strategy Paper, 2007-2013, 2007.

${ }_{44}$ European Commission, Karmenu Vella, China and Europe are working side by side to tackle global challenges, 2015 https://ec.europa.eu/commission/commissioners/2014-2019/vella/blog/china-and-europe-are-workingside-side-tackle-global-challenges_en, accessed 12 May 2018.
} 
Joint Statement on Climate Change signed in 2015 is a testimony of the common interest in learning from each other. 45

\section{EU environmental priorities regarding China}

The 2016 European Commission Communication "Elements for a new EU strategy on China" acknowledges that "the environment is now a top Chinese policy priority", as recognised by the 13th Five-Year Plan. "The EU should build on this to create a positive common agenda in areas such as tackling air, water and soil pollutions, the circular economy, sustainable management of ocean resources and fighting threat to habitats and biodiversity". ${ }^{6}$ China's 13th Five-Year Plan released in 2015 indeed stated that ensuring a "moderately prosperous society" by 2020 requires medium-high economic growth, higher living standards and a better quality environment. 47 The EU made protection of the environment a central pillar of its China policies and communications. The issue has gradually become an area of joint interest articulated in bilateral statements. In 2012 the two underlined the importance of water, food and nutrition security as a common interest, welcoming the establishment of the EU-China Water Platform.48

All EU Communications on China (1995, 1998, 2001, 2003, 2006, and 2016) indicate Europe gradually aimed to help China address its environmental challenges. Its 1998 Communication stressed "the EU should in particular help China integrate environmental priorities-such as the prevention of industrial pollution and greenhouse gas emissions, and the conservation of biological diversity-further into national economic policy-making processes and into development schemes at regional and local levels".49 The EU has encouraged tackling the issue as a global challenge, reflecting recognition of China's growing global relevance. The 2001 "EU Strategy towards China" noted that China's growing economic and political power meant "it is appropriate to involve it in the management of most major global issues, such as environmental degradation". ${ }^{\circ}$ In 2003 the EU committed to intensifying efforts to help China address emerging sustainability challenges, as "both the EU and China are, since 2001, engaged in a process of adaptation to a changing global environment". ${ }^{51} \mathrm{In}$ 2006 the Commission claimed it played a central role in finding sustainable solutions, and "has proved capable of exerting a progressive influence well beyond its borders". But, to tackle key challenges the EU needed to factor the China dimension into the full range of EU policies. $5^{2}$ And in 2016 the EU committed to encourage economic, environmental and social reforms in China towards a more open, sustainable and inclusive growth model.53

Statistics show the environmental industry sector has been one of the few flourishing economic sectors in Europe since the 2008 financial crisis. 54 And, according to Euro-

\footnotetext{
45 European Commission, EU-China Joint Statement on Climate Change, 2015.

${ }^{46}$ European External Action Service, Elements for a new EU strategy on China, 2016.

${ }_{47}$ China unveils proposal for formulating $13^{\text {th }}$ Five-year Plan, Xinhua, 2015,

http://news.xinhuanet.com/english/2015-11/o3/c_134780352.htm, accessed 13 May 2018.

${ }^{48}$ European External Action Service, Joint Press Communiqué $15^{\text {th }}$ EU-China Summit, 2012.

49 European Commission, Building a Comprehensive Partnership with China, 1998.

50 European Commission, EU Strategy towards China, 2001.

${ }^{51}$ European Commission, A maturing partnership, 2003.

${ }^{2}$ European Commission, EU-China: Closer partners, growing responsibilities, 2006.

${ }_{53}$ European External Action Service, Elements for a new EU strategy on China, JOIN (2016) 30 final, 2016.

${ }_{54}$ European Environment Agency, The European Environment state and outlook 2015,

http://www.eea.europa.eu/soer-2015/synthesis/report/oc-executivesummary, accessed 10 May 2018.
} 
barometer Europeans' concern about the environment remains high.55 This suggests public opinion remains a decisive force in articulating demands for further action. At the same time, environmental protection has gained increasing prominence in EUChina relations in accordance with Beijing's decision to prioritise it in its own development. Addressing environmental challenges has become an element of paramount importance on which the future of China's economic developments has come to depend. Beijing set the protection of the environment as a key goal, in line with the "great banner of socialism with Chinese characteristics". 56 This made addressing the issue of joint interest. In considering the EU's effectiveness in pursuing its priorities it is important to recognise that in European regional development policy a strong link connects environmental protection and sustainable development. This has enabled EU-China bilateral cooperation in this field. The EU has elaborated tools to promote harmonious development across its member states, between rich and poor regions, to contribute to its overall sustainable development. The largest single source of financing for environmental projects has been the Cohesion policy; out of a total budget of 344 billion euro, around 104 billion went towards environment-related actions for 2007-2013. ${ }^{57}$ In the process, a closely linked circle of European and national bodies, private and societal actors has developed, speaking the same technical language, going global via structured dialogue with China. ${ }^{8}$ Given that China has faced considerable regional development disparities between its booming coastal regions, the underdeveloped Western parts and the decline of traditional heavy industry in the North East, regional development including environmental protection has become a crucial matter of bilateral cooperation.59

The two sides launched regional cooperation following up on the commitments of the 7th China-EU Summit of 2004, in which balanced development and regional policy were identified as key areas. ${ }^{60}$ This suggests China recognised the success of the EU's Cohesion Policy as a powerful internal policy, which facilitated engagement. Externally, to coordinate the work of the many actors in European policy-making, the European strategy on environmental integration in external relations identified ways of pursuing the EU's core objectives in the conduct of external relations. ${ }^{61}$ The EU Green Diplomacy Network uses European and member states' diplomatic networks to ensure a more coherent message is transmitted to third countries. ${ }^{62}$ While there is consensus among member states on the importance of integrating the environment into EU-China relations, they display different visions and enter into bilateral agreements with China. In the assessment of former EU Ambassador to China, Marcus Ederer, while such collaboration is done at the level of member states, they are coordinated and supported by EU institutions, as they follow the EU 2020 strategy,

\footnotetext{
${ }_{55}$ European Commission, Special Eurobarometer 416, Attitudes of European Citizens Towards the Environment, September, 2014, http://ec.europa.eu/public_opinion/archives/ebs/ebs_416_en.pdf, accessed 13 May 2018. ${ }_{56}$ China's Twelfth Five Year Plan, 2011, http://cbi.typepad.com/china_direct/2011/o5/chinas-twelfth-five-newplan-the-full-english-version.html, accessed 10 May 2018.

57 European Commission, Cohesion policy and the environment, 2010, for more see

http://ec.europa.eu/environment/pubs/pdf/factsheets/cohesion.pdf, accessed on 10th of May 2018.

${ }^{5}$ European Commission, The turning point of EU Cohesion policy, Working Paper in "An Agenda for a reformed Cohesion Policy", 2009.

${ }_{59}$ European Commission's Regional Policy Cooperation/International Cooperation/China, for more see http://ec.europa.eu/regional_policy/en/policy/cooperation/international/china/, accessed 10 May 2018. ${ }^{60}$ European Council (2004). Joint Statement, the seventh EU-China Summit, 15065/04 (Presse 337), https://www.consilium.europa.eu/uedocs/cms_data/docs/pressdata/en/er/82998.pdf, accessed 10 May 2018. ${ }^{61}$ European Commission (2002). Environmental integration in external relations, Council strategy, http://eurlex.europa.eu/legal-content/EN/TXT/HTML/?uri=URISERV:l28166\&from=EN, accessed 10 May 2018.

${ }_{62}$ European External Action Service, EU Green Diplomacy Network,

http://eeas.europa.eu/environment/gdn/index_en.htm, accessed on 1oth of May, 2018.
} 
aligned with China's 12th Five-Year Plan, "offering many opportunities to work together". ${ }^{63}$ Notwithstanding the internal fragmentation, the above revealed a joint EU aspiration towards better policy coordination, both internally and externally. Faced with a series of crises in its 2016 Work Program, the Commission stressed "in many areas a common approach at European level is needed if we are to achieve our ambitious policy goals, including a high level of environmental protection". 64

While the EU's global leadership in this regard is widely recognised, its efforts to lead and set trends in environmental protection have found both critics and supporters. In response to skeptics who argue the EU has failed in its attempt to achieve a worldwide climate policy, some claim it has achieved much more than most realise; "countries across the world are increasingly modeling their policies on the EU example". 65 In particular the Chinese leadership pays a lot of attention to European legislation and models their own after it, interested in listening to European experiences. ${ }^{66}$ In 2013 China released a new action plan to cap coal consumption to below $65 \%$ of its total primary energy use by 2017.67 On the Emissions Trading Schemes (ETS), "Europe's provocative policy helped to shift countries and industries beyond their comfort zones." 68 While Europe took a risk by introducing a regional trading scheme that was widely opposed internationally, in the end it ensured a process to develop a universal scheme under the International Civil Aviation Organisation. By establishing a regional scheme, the EU created incentives for others by including exemptions for those undertaking equivalent actions, namely doing something to reduce emissions from aviation, thus cementing the case for a global aviation agreement (Gallagher, 2013). China launched the first of seven pilot ETS, covering four provinces and cities, $20 \%$ of China's emissions and 26\% of its GDP. Beijing has been seeking environmental technology to help shift its long-term path of economic growth, and policy experimentation across the country is testament to this effort.

\section{Water, air, waste, biodiversity and climate change}

In the identified priority areas, a perennial challenge facing China is the absence of adequate legislation and weak implementation of existing legislation. It is important to add that in the area of technical cooperation the EU has had to deal with a vast country, with a fundamentally different political system, indicative of their normative divergence. While the Chinese leadership has held on to its monopoly over environmental legislation with restricted public participation, in EU member states we have seen a proliferation of non-governmental actors involved, ensuring public consultation. European normative power has therefore had to face a complex set of challenges in China, coming with a fragmented structure of its own.

In regards to water, Chinese policymakers have considered international best practices to orient domestic policy development. For example, the China Europe Water

\footnotetext{
${ }_{63}$ European Commission, Science, Research and Innovation: Cooperation between the European Union, Member States and China, May, 2012, https://ec.europa.eu/research/iscp/pdf/sfic/co-operation-europe-chinamay-2012_en.pdf, accessed 13 May 2018.

${ }^{64}$ European Commission, Work Programme, No time for business as usual, Strasbourg, COM (2015) 610final, 2016, http://ec.europa.eu/atwork/pdf/cwp_2016_en.pdf, accessed 13 May 2018.

${ }_{5}$ L. Gallagher, Europe is not alone on climāe, 2013, http://www.energypost.eu/europe-is-not-alone-onclimate/, accessed 13 May 2018.

${ }^{66}$ Interview with Alessandro Celestino, Office at the Italian Ministry for the Environment, 21 March 2014.

${ }_{67}$ China reveals new plans to reduce air pollution, China.org, 2013, http://www.china.org.cn/environment/201309/12/content_30007807.htm, accessed 10 May 2018.

68 L. Gallagher, Europe is not alone on climate, 2013.
} 
Platform was established in 2012 to promote policy dialogue "based on mutual interest, mutual benefit and mutual funding". ${ }^{69}$ At the Annual High-Level Meeting in 2015 the two reinforced their determination to address mutual challenges deriving from water scarcity, overuse, and pollution. They expressed the ambition to act as an example of an international partnership that enhances implementation. ${ }^{70}$ The Platform is a regional component of the EU Water Initiative, administered by two secretariats, hosted by the Ministry of Water Resources on behalf of China and by the Ministry of the Environment of Denmark on behalf of the EU. Since its establishment, many initiatives have been successfully conducted. For example, in July 2016 at the EUChina strategic knowledge exchange on groundwater policy, a legislation and standards meeting brought together eleven experts from the EU and China. ${ }^{71}$ Similarly, under Horizon 2020 projects, such as the PIANO project (Policies, Innovation and Networks for enhancing opportunities for China Europe Water Cooperation) the objective is to create a strategic cooperation partnership for water research and innovation between 2015 and 2018. It is executed by a consortium of nine leading European partners and thirteen leading Chinese partners, coordinated by an Austrian university and with the participation of Denmark, France, Italy, Portugal, Sweden, UK and Germany. 72 European technological water innovations with potential for application in China are identified.73 These examples suggest European expertise has proved attractive to China. At the same time, domestic legitimacy considerations, including increasing public demand for access to safe drinking water, impelled Beijing to ensure access and to address water scarcity, in order to safeguard its "unique model of governance" that "transformed the ancient middle kingdom into the world's second largest economy".74

Air pollution problems in China are also related, in part, to imperfect legislation and potential integration problems among legislation, plans and policies.75 In 2010, China became the world's largest energy consumer, and in 2014 the Global Carbon Project reported that its emissions per capita exceeded those of the EU. ${ }^{6}$ As in the case of water, efforts addressing air pollution have traditionally faced three major challenges: enforcing environmental laws, taking polluters to court and enhancing transparency. ${ }^{77}$ EU-China practical cooperation has materialised on this front too. The two partners signed a 15-million-euro EU-funded program, the EU-China Environmental

\footnotetext{
${ }_{69}$ China Europe Water Platform, https://www.eip-water.eu/cewp-china-europe-water-platform , accessed 10 May 2018.

70 China Europe Water Platform, Annual High-Level Meeting, 2015, https://circabc.europa.eu/sd/a/6882630ca330-4c25-agfe-76877552052d/Presentation\%252c\%20China-Europe\%20Water\%20Platform\%20-

\%20Status\%20of\%20Water\%20Quality\%20Co-Lead\%2oProgramme.pdf, accessed 13 May 2018.

${ }^{71}$ China Europe Water Platform, EU-China Strategic Knowledge Exchange on Groundwater Policy, Legislation and Standards, June, 2016.

${ }^{72}$ CORDIS, PIANO, Horizon2020, 2015, http://cordis.europa.eu/project/rcn/193911_en.html accessed 13 May 2018.

73 Danish Water Forum, Enhancing Opportunities for China Europe Water Collaboration: Ambitions of the H2O2O PIANO project, Technical University of Denmark, 2015.

http://www.danishwaterforum.dk/Docs/2015/Presentations/ST\%20Session\%20WWF7/Ambitions\%20of\%20the \%20H2020\%20PIANO\%20project\%20-\%20Bart\%20Smets.pdf, accessed 13 May 2018.

${ }_{74}$ China Voice: What if China had taken a different path? Xinhua, 2015,

http://news.xinhuanet.com/english/2015-03/10/c_134055520.htm accessed 13 May 2018.

75 For a detailed overview of the pertinent legislation, plans and policies in China see L. Feng and W. Liao, Legislation, plans and policies for prevention and control of air pollution in China: achievements, challenges and improvements, Journal of Cleaner Production, vol. 112, part 2, 20 January, 2016, pp. 1549-1558.

${ }^{76}$ D. Seligsohn, The dragon morphs, New Scientist, November, vol. 228, 2015, issue 3049.

77 Disclosure on pollution improves but major gaps remain, China Dialogue, 2015,

https://www.chinadialogue.net/blog/8138-Disclosure-on-pollution-improves-but-major-gaps-remain/en accessed 13 May 2018.
} 
Governance Program (ECEGP) for 2010-2015 to enhance governance issues in China, based upon the principles of the Aarhus Convention: public access to environmental information, public participation in planning and decision-making, access to justice and corporate environmental responsibility. In the fifteen Partnership Projects European entities work together with local governments, and in each partnership a European approach is presented in order to test and put into practice new ideas. ${ }^{8}$ For example, the Hubei Air Quality Information and Early Warning System, established an up-to-date air quality information system for nine cities in Hubei to provide more accurate and adequate information to the public. 79 The team leader of the Program, Dimitri de Boer said that "the experiences of EU countries in managing the environment over dozens of years will be helpful in improving China's environment governance". ${ }^{80}$ The Program was positively reported in official Chinese media as a collaboration "to reduce the harm to society and civilians caused by pollution and ineffective environmental management”. This indicates that Europe has been China's partner in air protection.

Currently China is the world's largest waste generator. In the context of urbanisation, China has transformed from one of the most egalitarian countries to one with the highest level of social inequality. ${ }^{81}$ As populations are increasingly concentrated in cities, dealing with waste management involves psychological, political and economic factors. ${ }^{82}$ Therefore managing waste remains an urgent issue for Beijing to address. Research suggests that for the EU "there is a real need and opportunity to actively work with China on waste management; EU entities will need to "recognize the progress China has made, understand evolving policy and challenges, treat China as an equal partner, and adapt their responses". 83 Discourse analysts consider the EU as a major contributor, along with the OECD or the UN Environmental Program, to shaping discourse within the waste policy domain around concepts such as "waste prevention and reduction" or "materials cycles". The EU in particular has driven the emergence of the concept of "zero waste". In the process of articulating and effectively disseminating such keywords, policy labels are important, and repetition, increased visibility and intertextual links directly contribute to problem identification. ${ }^{84}$ The EU also has high levels of expert knowledge in the field of recycling; some of its policies, such as the EU Directive on Restriction of Hazardous Substances, are internationally influential and believed to be used as the basis for policies and regulations in China. 85 In 2015, Environment Commissioner Karmenu Vella said that Chinese waste management

\footnotetext{
${ }^{78}$ EU-China Environmental Governance, http://www.ecegp.com/english/aboutus/aboutus.asp, accessed 13 May 2018.

${ }^{79}$ Hubei air quality information and early warning system - complementing Hubei “ $1+8$ ” city cluster haze monitoring, http://www.hubei-aq.info/

${ }^{80}$ Y. Gong, China, EU collaborate on environmental governance (2014). China.org, 2014, http://www.china.org.cn/environment/2014-04/04/content_32003044.htm

${ }^{81}$ Z. Zhao, 'Economic inequality, status perceptions and subjective well-being in China's transitional economy. Research in Social Stratification and Mobility' in L. Xiao, T. Lin, S. Chen, G. Zhang, Z. Ye, Z. Yu, Characterizing Urban Household Waste Generation and Metabolism Considering Community Stratification in a Rapid Urbanizing Area of China, December 2015, 30 (4): 433-450.

${ }^{82}$ N. Wiggington, J. Yeston, and D. Malakoff, More Treasure Than Trash, Science, vol. 337, issue 6095 (2012): 662-663.

${ }_{83}$ Europe China Research and Advice Network (ECRAN), Short Term Policy Brief 36, 2010/256-524, March 2012. ${ }^{84}$ A. Silva, L. Stocker, P. Mercieca, M. Rosano, The role of policy labels, keywords and framing in transitioning waste policy, Journal of Cleaner Production, vol. 115, 2016, pp. 224-237; see also J. S. Dryzek, The Politics of the Earth, Environmental Discourses, Third Edition, Oxford. 2013.

85 ECRAN, 2014: op. cit., p. 25.
} 
legislation on the control of pollution caused by electronic information products is modelled on European legislation. ${ }^{86}$

Most Chinese laws on biodiversity remain vague; they suffer from poor implementation and weak enforcement. ${ }^{87}$ The EU's record in setting up its own policy in alignment with international standards as well as its strong implementation record have shaped its leverage over China in this field. Europe's 2020 Biodiversity Strategy reflects international legal instruments, ranging from the 1992 Convention on Biological Diversity to the 2010 ten-year Nagoya Strategic Plan to combat biodiversity loss. 88 The 2020 Strategy is underpinned by the recognition that biodiversity has significant economic value seldom captured in markets, and recommended the economic value of biodiversity be factored into decision making. Considered as Europe's contribution, this point was incorporated into the Nagoya Plan and set as a global target. ${ }^{89}$ According to the EEAS, the EU-China Biodiversity Program (20062011) has contributed to improving conservation by supporting China in its implementation of the Convention on Biological Diversity. ${ }^{\circ}$ The EU has contributed 30 million euro to an external aid program, managed by the European Delegation in China. It has also claimed the program "has transformed the way biodiversity is regarded in China and the way it will be protected in the future". ${ }^{91}$ European experts and funding have taken part in the drafting of China's National Biodiversity Strategy, helping embed conservation as a major mitigation tool in China's response to climate change. At the closure of the Program in 2011, then EU Ambassador Markus Ederer said "biodiversity is our common lifeline". ${ }^{2}$ Cooperation helped local governments to include biodiversity protection in their local economic and social development plans Vice Minister for the Environment Li Ganjie added.93 In addition, the Program made efforts to promote the awareness of biodiversity among the public. As a result, it demonstrated the usefulness of introducing a bottom-up approach in order to improve the strategic partnership in climate change matters. Through its power of example, Europe has played an important role in China's conservation efforts. In fact, Europe has shed light on an essential aspect of China's own development by explicitly highlighting the economic and social cost of the loss of biodiversity.

China has made progress in moving towards international standards, reinforcing its global relevance. Beijing has engaged in numerous international agreements and built up global cooperation in climate change. The EU, as a formally recognised actor in the international climate regime, has engaged China through its external climate policy. The EU is widely perceived as a classic norm entrepreneur, an actor that defined

\footnotetext{
${ }^{86}$ European Commission, 2015, Karmenu Vella, op. cit.

${ }_{87}$ W. Yu, J. J. Czarnezki, Challenges to China's Natural Resources Conservation and Biodiversity Legislation, Environmental Law, vol. 43, no. 125, Vermont Law School Research Paper, 2013, pp. 12-21.

${ }^{88}$ For more on European Biodiversity Policy, see

http://ec.europa.eu/environment/nature/biodiversity/international/cbd/index_en.htm

89 European Commission, Our life insurance, our natural capital: an EU biodiversity strategy to 2020, 3.5.2011, COM (2011) 244 final, 2011, http://eur-lex.europa.eu/legal-

content/EN/TXT/PDF/?uri=CELEX:52011DCo244\&from=EN, accessed 13 May 2018.

${ }_{90}$ M. Noguera, The EU-China Strategic Partnership in Climate Change: The Biodiversity Programme, EU

Diplomacy Papers, 02, College of Europe, 2011.

${ }^{11}$ European External Action Service, A Legacy of EU-China Cooperation on Biodiversity: Closure Workshop of EU-China Biodiversity Program held in Beijing 14/o9, 2011,

http://eeas.europa.eu/delegations/china/press_corner/all_news/news/2011/20110914_01_en.htm accessed 13 May 2018.

${ }_{92}$ European External Action Service, A Legacy of EU-China Cooperation on Biodiversity. op.cit.

${ }_{93}$ China willing to enhance biodiversity co-op with EU, Xinhua, 2011, http://www.chinadaily.com.cn/china/201105/21/content_12553497.htm, accessed 13 May 2018.
} 
climate change action as a moral and ethical issue that must transcend narrow economic interests. 94 This clearly suggests the EU has set an example in the field, going beyond its internal governance complexities. In fact, the EU claims the EU Green Diplomacy Network has contributed to the creation of a new "culture" in the area of sustainable development. 95 Research also suggests the EU-China dialogue on car exhaust emission standards has led to China adopting EU rules. ${ }^{6}$ There is a consensus that no other area has as much potential for fruitful cooperation between the two parties as climate change, but there is also no area where the room for confrontation is so great. 97 In the words of the Director General of the European Commission's DG CLIMA, Europe is committed to becoming the most climate-friendly region in the world through continued leadership in fighting climate change and through international negotiations. ${ }^{88}$ In his State of the Union speech delivered on 10 September 2015, Commission President Jean-Claude Juncker said Europe's priority is an ambitious, robust and binding global climate deal; "I do not want a Europe that stands on the sidelines of history. I want a Europe that leads. When the European Union stands united, we can change the world", he said naming climate change as example of where Europe is already leading. 99

\section{Conclusion}

This article identified technical cooperation in all priority areas through which Europe has promoted international environmental standards in China. Cooperation has been of mutual interest, hence a key pillar of the strategic partnership. The Chinese leadership has shown significant interest in learning from Europe, and willing to model their policies on the European approach. To a great extent this is a result of Europe's global leadership in environmental protection; the EU has set a good example at home. At the same time the weight of China's domestic considerations has been significant, indicating the strong impact of Beijing's national interests in shaping the Chinese leadership's willingness and readiness to work together with European partners. This means that Beijing's ambitions to become a global power have made working with Europe necessary. Therefore, through Europe's power of example in a constructivist framework, and China's power of interest in a realist approach, cooperation materialised in air, water, waste, biodiversity and climate change. Addressing the challenges through joint projects, Europe has provided expertise, indicative of its normative power in shaping China's approach to environmental protection.

\section{Bibliography}

Acharya, A. The End of American World Order, Polity Press, 2014.

\footnotetext{
${ }_{94}$ M. A. Schreurs and Y. Tiberghien, Multi-level reinforcement: explaining European Union leadership in climate change mitigation, Global Environmental Politics, 7:4, 2007.

${ }_{95}$ The EU Green Diplomacy Network, http://eeas.europa.eu/environment/gdn/docs/gdn_more_en.pdf, accessed 13 May 2018.

$9^{6}$ C. Grant, and K. Barysch, Can Europe and China shape a new world order? Centre for European Reform, 2008. ${ }_{97}$ European External Action Service, A Legacy of EU-China Cooperation on Biodiversity p. 70.

${ }_{98}$ European Commission, Climate Action, http://ec.europa.eu/clima/about-us/director/index_en.htm, accessed 13 May 2018.

99 European Commission, State of the Union 2015: Time for Honesty, Unity and Solidarity, 2015,

http://europa.eu/rapid/press-release_SPEECH-15-5614_en.htma, accessed 13 May 2018.
} 
Allen, D. and M. Smith. 'Western Europe's Presence in the Contemporary International Arena' in M. Holland, (ed.), The Future of European Political Cooperation: Essays on Theory and Practice, New York: St. Martin Press, 1991.

Backgrounder: Xi Jinping Thought on Socialism with Chinese Characteristics for a New Era. Xinhua, 2018, http://www.xinhuanet.com/english/201803/17/c_137046261.htm accessed 24 May 2018.

Barysch, K. A New Reality for the European Union, Council on Foreign Relations, September, 2010.

Bull, H. Civilian Power Europe: A Contradiction in Terms? Journal of Common Market Studies, Vol. 21, No. 2 (1982): 149-64.

China's call for multilateralism at G20 summit echoed by experts worldwide. Xinhua, 2018, http://www.xinhuanet.com/english/2018-12/o2/c_137644628.htm, accessed 7 April 2019.

China Europe Water Platform, Annual High-Level Meeting, 2015, https://circabc.europa.eu/sd/a/6882630c-a330-4c25-a9fe-76877552052d/Presentation\%252c\%20China-Europe\%20Water\%20Platform\%20-\%20Status\%200f\%20Water\%20Quality\%20Co-Lead\%20Programme.pdf, accessed 13 May 2018.

China Europe Water Platform, EU-China Strategic Knowledge Exchange on Groundwater Policy, Legislation and Standards, June, 2016.

China Europe Water Platform, https://www.eip-water.eu/cewp-china-europe-waterplatform , accessed 10 May 2018.

China reveals new plans to reduce air pollution, China.org, 2013, http://www.china.org.cn/environment/2013-09/12/content_30007807.htm, accessed 10 May 2018.

China unveils proposal for formulating $13^{\text {th }}$ Five-year Plan, Xinhua, 2015, http://news.xinhuanet.com/english/2015-11/o3/c_134780352.htm, accessed 13 May 2018.

China Voice: What if China had taken a different path? Xinhua, 2015, http://news.xinhuanet.com/english/2015-03/10/c_134055520.htm accessed 13 May 2018.

China willing to enhance biodiversity co-op with EU, Xinhua, 2011, http://www.chinadaily.com.cn/china/2011-05/21/content_12553497.htm, accessed 13 May 2018.

China's Xi Jinping urges dialogue, not confrontation, at Boao Forum after Trump seeks tariffs, The Straits Times, 2018, http://www.straitstimes.com/asia/eastasia/chinas-xi-says-opening-brings-progress-closure-leads-to-backwardness-atboao-forum, accessed 12 May 2018.

Chinese dream is a dream for all. Xinhua, 2016, http://www.xinhuanet.com/english/2016-12/03/c_135878166.htm, accessed 10 May 2018.

Comments by President Xi on eco-environmental protection, China Environment Media, 2016, 
http://www.chinaenvironment.info/Important_Message/201602/t20160222_24137 .html, accessed 13 May 2018.

Constitution of the People's Republic of China, Full text after amendment on March 14, 2004, available at http://www.npc.gov.cn/englishnpc/Constitution/200711/15/content_1372964.htm, accessed 16 May 2018.

Cordis, Piano, Horizon2020, 2015, http://cordis.europa.eu/project/rcn/193911_en.html, accessed 13 of May 2018.

Danish Water Forum, Enhancing Opportunities for China Europe Water Collaboration: Ambitions of the H2O2O PIANO project, Technical University of Denmark, 2015. available at http://www.danishwaterforum.dk/Docs/2015/Presentations/ST\%20Session\%20WWF7/Ambitions\%20of\%20the\%20 H2020\%20PIANO\%2Oproject\%20-\%20Bart\%20Smets.pdf, accessed 13 May 2018.

de Jonquières, G. 'China's economic strategy: what power shift to China?' in N. Kitchen (ed.) IDEAS - special reports, The London School of Economics and Political Science, London, UK, 2012.

Diez, T. Constructing the Self and Changing Others: Reconsidering 'Normative Power Europe', University of Birmingham, 2005.

Disclosure on pollution improves but major gaps remain, China Dialogue, 2015 , https://www.chinadialogue.net/blog/8138-Disclosure-on-pollution-improves-butmajor-gaps-remain/en accessed 13 May 2018.

Doidge, M. 'Regional organization as actors in international relations.

Interregionalism and assymetric dialogues', in J. Rüland, G. Schubert, C. Schucher and Cornelia Storz (eds.) Asian-European Relations, Building blocks for global governance? Routledge Contemporary Asia Series, $1^{\text {st }}$ edition, 2008.

Dollar, D., R. Hyas, and J.A. Bader. Assessing US-China relations 2 years into the Trump presidency, Brookings, January 15, 2019, https://www.brookings.edu/blog/order-from-chaos/2019/01/15/assessing-u-s-china-relations-2-years-into-thetrump-presidency/, accessed 6 April 2019.

Dryzek, J. S. The Politics of the Earth, Environmental Discourses, Third Edition, Oxford. 2013.

Duchêne, F. 'The European Community and the Uncertainties of interdependence', in M. Kohnstamm and W. Hager (eds.) A Nation Writ Large? Foreign-Policy Problems before the European Community, London, Macmillan, 1973.

EU-China Environmental Governance, http://www.ecegp.com/english/aboutus/aboutus.asp, accessed 13 May 2018.

European Commission (2002). Environmental integration in external relations, Council strategy, http://eur-lex.europa.eu/legalcontent/EN/TXT/HTML/?uri=URISERV:128166\&from=EN, accessed 10 May 2018.

European Commission, A maturing partnership, 2003. 
European Commission, Building a Comprehensive Partnership with China, 1998.

European Commission, China Strategy Paper, 2007-2013, 2007.

European Commission, Climate Action, http://ec.europa.eu/clima/aboutus/director/index_en.htm, accessed 13 May 2018.

European Commission, Cohesion policy and the environment, 2010, for more see http://ec.europa.eu/environment/pubs/pdf/factsheets/cohesion.pdf, accessed 10 May 2018.

European Commission, EU Strategy towards China, 2001.

European Commission, EU-China Joint Statement on Climate Change, 2015.

European Commission, EU-China: Closer partners, growing responsibilities, 2006.

European Commission, Joint Communication to the European Parliament, the European Council and the Council, EU-China - A strategic outlook, https://ec.europa.eu/commission/sites/beta-political/files/communication-euchina-a-strategic-outlook.pdf, accessed 6 April 2019.

European Commission, José Manual Durao Barroso State of the Union 2012 Address, 2012, http://europa.eu/rapid/press-release_SPEECH-12596_en.htm?locale=en, accessed 10 May 2018.

European Commission, Karmenu Vella, China and Europe are working side by side to tackle global challenges, 2015, https://ec.europa.eu/commission/commissioners/2014-2019/vella/blog/china-andeurope-are-working-side-side-tackle-global-challenges_en, accessed 12 May 2018.

European Commission, Our life insurance, our natural capital: an EU biodiversity strategy to 2O2O, 3.5.2011, COM (2011) 244 final, 2011, http://eurlex.europa.eu/legal-content/EN/TXT/PDF/?uri=CELEX:52011DC0244\&from=EN, accessed 13 May 2018.

European Commission, Rio+20: towards the green economy and better governance, Brussels, COM (2011)363final, 2011, http://eur-lex.europa.eu/legalcontent/EN/TXT/PDF/?uri=CELEX:52011DCo363\&from=EN, accessed 7 May 2018.

European Commission, Science, Research and Innovation: Cooperation between the European Union, Member States and China, May, 2012, https://ec.europa.eu/research/iscp/pdf/sfic/co-operation-europe-china-may2012_en.pdf, accessed 13 May 2018.

European Commission, Special Eurobarometer 416, Attitudes of European Citizens Towards the Environment, September, 2014, http://ec.europa.eu/public_opinion/archives/ebs/ebs_416_en.pdf, accessed 13 May 2018.

European Commission, State of the Union 2015: Time for Honesty, Unity and Solidarity, 2015, http://europa.eu/rapid/press-release_SPEECH-15-5614_en.htma, accessed 13 May 2018. 
European Commission, The turning point of EU Cohesion policy, Working Paper in "An Agenda for a reformed Cohesion Policy", 2009.

European Commission, Work Programme, No time for business as usual, Strasbourg, COM (2015) 610final, 2016, http://ec.europa.eu/atwork/pdf/cwp_2016_en.pdf, accessed 13 May, 2018.

European Commission's Regional Policy Cooperation/International Cooperation/China, for more see http://ec.europa.eu/regional_policy/en/policy/cooperation/international/china/, accessed 10 May 2018.

European Council (2004). Joint Statement, the seventh EU-China Summit, 15065/04 (Presse 337), https://www.consilium.europa.eu/uedocs/cms_data/docs/pressdata/en/er/82998.pdf, accessed 10 May 2018.

European Environment Agency, The European Environment state and outlook 2015, http://www.eea.europa.eu/soer-2015/synthesis/report/oc-executivesummary, accessed 10 May 2018.

European External Action Service, A Legacy of EU-China Cooperation on Biodiversity: Closure Workshop of EU-China Biodiversity Program held in Beijing 14/o9, 2011, http://eeas.europa.eu/delegations/china/press_corner/all_news/news/2011/20110914_01_en.htm accessed 13 May 2018.

European External Action Service, Elements for a new EU strategy on China, 2016.

European External Action Service, Elements for a new EU strategy on China, JOIN (2016) 30 final, 2016.

European External Action Service, EU Green Diplomacy Network, http://eeas.europa.eu/environment/gdn/index_en.htm, accessed 10 May 2018.

European External Action Service, EU-China Summit joint statement, The way forward after forty years of EU-China cooperation, 2015.

European External Action Service, Joint Press Communiqué $15^{\text {th }}$ EU-China Summit, 2012.

European Union, the Council, Regulation of the European Parliament and of the Council establishing a framework for the screening of foreign direct investment into the Union, https://data.consilium.europa.eu/doc/document/PE-72-2018INIT/en/pdf, accessed 7 April 2019.

Feng, L. and W. Liao. Legislation, plans and policies for prevention and control of air pollution in China: achievements, challenges and improvements, Journal of Cleaner Production, vol. 112, part 2, 20 January (2016): 1549-1558.

Gallagher, L. Europe is not alone on climate, 2013, http://www.energypost.eu/europe-is-not-alone-on-climate/, accessed 13 May 2018.

Gottwald, J.-C., A. Cottey and N. Underhill. 'The European Union and China: Status, Issues, Prospects' in N. Sausmikat, K. Fristsche, (eds.) Civil Society in European- 
Chinese Relations, Challenges of Cooperation, EU-China Civil Society Forum, 2010, https://www.tni.org/files/download/eu-china-civil-society.pdf, accessed 7 May 2018.

Gong, Y. China, EU collaborate on environmental governance (2014). China.org, 2014, http://www.china.org.cn/environment/2014-04/04/content_32003044.htm accessed 13 May 2018.

Grant, C. and K. Barysch. Can Europe and China shape a new world order? Centre for European Reform, 2008.

Groenleer, M. L. P. and L. G. Van Schaik. United we stand? The European Union's International Actorness in the Cases of the International Criminal Court and the Kyoto Protocol, Journal of Common Market Studies., vol. 45, nr. 5 (2007): 969-998.

Holslag, J. China's energy policy in the light of climate change, and option for cooperation with the EU, Policy Department Economic and Scientific Policy, European Parliament, 2007, http://www.europarl.europa.eu/RegData/etudes/etudes/join/2007/393501/IPOL-JOIN_ET(2007)393501_EN.pdf, accessed 10 May 2018.

Hubei air quality information and early warning system - complementing Hubei “ $1+8$ ” city cluster haze monitoring, http://www.hubei-aq.info/

Ikenberry, G. J. The Rise of China and the Future of the West, Foreign Affairs, January/February, 2008.

Interview with Alessandro Celestino, Office at the Italian Ministry for the Environment, 21 March 2014.

Kent, A. Compliance $v$ Cooperation: China and International Law, Australian International Law Journal, vol. 13 (2008): 19-32.

Li, A. H. F. Hopes of Limiting Global Warming? China and the Paris Agreement on Climate Change, China Perspectives, 2016.

Li says Beijing will keep buying European bonds, China Daily, 2015, http://usa.chinadaily.com.cn/epaper/2015-06/30/content_21143082.htm, accessed 10 May 2018.

Manners, I. Normative Power Europe: The International Role of the EU, Panel discussion: The European Union between International and World Society, European Community Studies Association, Madison, Wisconsin, USA, 2001.

Ministry of Foreign Affairs of the PRC, China's Initiation of the Five Principles of Peaceful Co-existence, http://www.fmprc.gov.cn/mfa_eng/ziliao_665539/3602_665543/3604_665547/t18053.shtml, accessed 13 May 2018.

Noguera, M. P. The EU-China Strategic Partnership in Climate Change: The Biodiversity Programme, EU Diplomacy Papers, 02, College of Europe, 2011.

Onuf, N. Worlds of Our Making: The Strange Career of Constructivism in International Relations, Columbia, SC, University of South Carolina Press, 1989. 
President Xi calls for Intensified Environmental Protection, Yibada, 2016 http://en.yibada.com/articles/109107/20160312/president-xi-calls-intensifiedenvironmental-protection.htm

Research in Social Stratification and Mobility' in L. Xiao, T. Lin, S. Chen, G. Zhang, Z. Ye, Z. Yu (eds.). Characterizing Urban Household Waste Generation and Metabolism Considering Community Stratification in a Rapid Urbanizing Area of China, 30 (4) (2015): 433-450.

Schreurs, M. A. and Y. Tiberghien. Multi-level reinforcement: explaining European Union leadership in climate change mitigation, Global Environmental Politics, 7:4, 2007.

Schulze, K. and J. Tosun. External dimensions of European environmental policy: An analysis of environmental treaty ratification by third states, European Journal of Political Research, 52 (2013): 581-607.

Seligsohn, D. The dragon morphs, New Scientist, November, vol. 228, 2015, issue 3049.

Selin,H. and S. D. VanDeveer. Broader, Deeper and Greener: European Union Environmental Politics, Policies, and Outcomes, The Annual Review of Environment and Resources, 40 (2015): 309-335.

Silva, A., L. Stocker, P. Mercieca, and M. Rosano. The role of policy labels, keywords and framing in transitioning waste policy, Journal of Cleaner Production, vol. 115, 2016, pp. 224-237.

Shi, Z. China-EU Relations: Crisis and Opportunity, The Diplomat, 2016, http://thediplomat.com/2016/o3/china-eu-relations-crisis-and-opportunity/ accessed 12 May 2018.

Smith, K. Beyond the Civilian Power EU Debate, Politique européenne, No. 17 (2005): 63-82.

Tan, D. The War of Water Pollution, ChinaWater Risk, 2014.

The EU Green Diplomacy Network, http://eeas.europa.eu/environment/gdn/docs/gdn_more_en.pdf, accessed 13 May 2018.

The New York Times, In New Slap at China, U.S. Expands Power to Block Foreign Investment, https://www.nytimes.com/2018/10/10/business/us-china-investmentcfius.html, Oct. 10, 2018, accessed 7 April 2019.

Trott, W. An Analysis of civilian, military and normative power in EU foreign policy, University of Leeds, POLIS Journal vol. 4, 2010.

Xi Jinping speech delivered at the 19th National Congress of the Communist Party of China, Xinhuanet, 2017, http://www.xinhuanet.com/english/download/Xi_Jinping's_report_at_19th_CPC_National_Congress.pdf, accessed 12 May 2018. 
Xi speaks for developing countries in UN, offers new outlook on development, int'l relations, Xinhuanet, 2015, http://www.xinhuanet.com/english/china/201509/29/c_134671859.htm, accessed 7 May 2018.

Vogler, J. and H. R. Stephan. The European Union in Global Environmental Governance: Leadership in the Making? International Environmental Agreements, 7 (2007): 389-413.

Wagner, M. and C. Brinkmann. Global Environmental Governance: A European Perspective, European Essay no. 36, The Federal Trust for education and research, 2005.

Wendt, A. Social Theory of International Politics, Cambridge Studies in International Relations, Cambridge University Press, 1999.

Whitman, R. Road Map for a Route March? De-civilianizing through the EU's Security Strategy, European Foreign Affairs Review 11 (2006): 1-15.

Whitman, R. The Fall, and Rise, of Civilian Power Europe? National Europe Center paper, 2002, no. 16.

Wiggington, N., J. Yeston, and D. Malakoff, More Treasure Than Trash, Science, vol. 337, issue 6095 (2012): 662-663.

Yu, W. and J. J. Czarnezki, Challenges to China's Natural Resources Conservation and Biodiversity Legislation, Environmental Law, vol. 43, no. 125, Vermont Law School Research Paper (2013): 12-21.

Zhao, Z. 'Economic inequality, status perceptions and subjective well-being in China's transitional economy. http://cbi.typepad.com/china_direct/2011/o5/chinas-twelfthfive-new-plan-the-full-english-version.html, accessed 10 May 2018. 